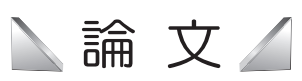

Original Paper

\section{非整数階微分を含む移流分散方程式を用いた トレーサー解析によるき裂構造推定に関する研究 *}

\title{
Characterization of Tracer Responses in Fractured Geothermal Reservoirs Based on Fractional Derivative Mathematical Model for Estimation of Fracture Distribution in Geothermal Reservoirs
}

\author{
by Hiroshi MAKITA ${ }^{\mathrm{a}}$, Anna SUZUKI ${ }^{\mathrm{a}}$, Takumi IWAGAKI ${ }^{\mathrm{a}}$, \\ Yuichi NIIBORI ${ }^{\mathrm{b}}$ and Toshiyuki HASHIDA ${ }^{\mathrm{b}^{*}}$
}

a. Graduate School of Environmental Studies, Tohoku University, Aramaki-Aza-Aoba 6-6-11707, Aobaku, Sendai 980-8579, Japan

b. Professor, Department of Engineering, Tohoku University (*Corresponding author, E-mail: hashida@rift.mech.tohoku.ac.jp)

\begin{abstract}
Tracer tests are often performed to obtain hydraulic parameters and to model geothermal reservoir systems. The Advection-Dispersion Equation (ADE) based on Fick's law has generally been used to describe the mass transport in the underground. However, this conventional model cannot describe mass transport correctly in the highly complex media such as fractured reservoirs. In this study, the fractional Advection-Dispersion Equation (fADE) has been utilized to calibrate tracer curves instead of the classical ADE. We investigate the relationship between flow parameters involved in the fADE and fractal dimension to explore the feasibility of predicting fractal dimensions of fractured rock masses based on the fADE. We simulate tracer transports employing fracture network models where the fractal dimensions are in the range of 2.0-3.0. It is shown that the fADE parameters correspond closely to the characteristic properties of the fracture networks. This indicates the fADE model based on fractal geometry is capable of capturing key aspects of flow and transport in fractured reservoirs and of predicting fractal dimensions of fractured rock masses by tracer tests.
\end{abstract}

KEY WORDS: Fractured Reservoir, Tracer Analysis, Fractal Dimension, fADE

\section{1. 緒言}

世界でも有数の火山国である我が国においては地熱エネルギー のポテンシャルは大きく, 自然エネルギーとしての地熱の果たす 役割は大きい。一般に，地熱発電は $70 \%$ を超える高い稼働率を 有することが特徵であり, ベース電源として電力供給における基 礎的役割を担うことが期待される。抽熱のためには, 高温の岩体, 水ならびに水の通路となる地下き裂が存在することの三条件が成 立していることが前提となる。従って，地熱開発のためには開発 対象となる地熱貯留層の構造, 特に地下き裂構造を把握しておく ことが必要である。

地下構造ならびに流動特性の把握のためにトレーサー試験が行 われている ${ }^{1)}$ 。トレーサー試験では一つの坑井から化学物質な

*2014 年 7 月 11 日受付 2014 年 10 月 21 日受理

1. 東北大学大学院 環境科学研究科 環境科学専攻

2. 学生会員 東北大学大学院 環境科学研究科環境科学専攻

3. 正会員東北大学大学院丁学研究科 量子エネルギー学専攻 教授

4. 正会員東北大学大学院工学研究科附属エネルギー安全科学研究セン タ一教授

[ 著者連絡先 ] FAX: 022-795-4311

E-mail: hashida@rift.mech.tohoku.ac.jp

キーワード : 断裂型貯留層, トレーサー応答, フランタル次元, fADE
どのトレーサー物質を投入し，もう一つの坑井にて時間経過に伴 ら濃度変化を測定する。時間経過に伴う濃度変化をトレーサー応 答と呼ぶ。得られたトレーサー応答と, トレーサーが移行する現 象を記述する数学モデルとの比較を通じて, 物理パラメータの推 定が可能となる。物理パラメータとは, 岩体中の対象物質の輸送 速度や，物質の分散による広がりの度合いを示す分散係数等があ げられる。従来より, 数学モデルとして均質媒体であることを前 提とした Fick 則が主に利用されてきた。Fick 則に基づく移流分 散方程式 (Advection-Dispersion Equation) を(1) 式に示す。

$$
\frac{\partial c(x, t)}{\partial t}=-u \frac{\partial c(x, t)}{\partial x}+D \frac{\partial^{2} c(x, t)}{\partial x^{2}}
$$

$u$ は地下水のダルシー流速, $D$ は分散係数, $c$ は濃度, $t$ は時間, $x$ は距離である。

地熱貯留層は, その内部に複数の地下き裂が存在し, 岩体を構 成する岩石種も様々であることから, 複雑で不均質な媒体である。 そのため, Fick 則を用いた数学モデルではnon-Fickian 挙動と呼 ばれる複雑媒体中での流動現象を正確に表現できないことが報告 されている ${ }^{2,3)}$ 。近年, Fick 則によらない新たな流動モデルとし て非整数階微分を含む移流分散方程式が提案されている ${ }^{4,5)}$ 。特 


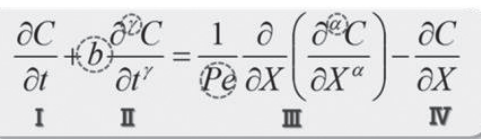

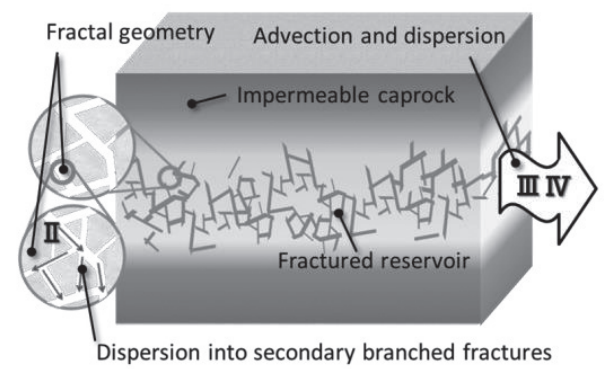

Fig.1 Schematic of a fractured reservoir and fADE model.

に Fomin らはFig. 1 の模式図で示されるようなフラクタル性を 有する天然き裂分布からなる貯留層に対して，(2) 式で与えられ る非整数階微分を含む移流分散方程式を導出している ${ }^{6,7)}$ 。

$$
\frac{\partial C}{\partial T}+b \frac{\partial^{\gamma} C}{\partial T^{\gamma}}=\frac{1}{P e} \frac{\partial}{\partial X}\left(\frac{\partial^{\alpha} C}{\partial X^{\alpha}}\right)-\frac{\partial C}{\partial X}
$$

$C$ は無次元濃度, $X$ は無次元距離, $T$ は無次元時間, $P e$ はペクレ 数を表す。また, $\alpha, \gamma, b$ および $P e$ は流動特性を決めるパラメー 夕となっており, $0<\alpha \leq 1,0<\gamma \leq 1$ を満たす。貯留層はフラク タル性を有する天然き裂, 寸なわち自己相似性を有するき裂群が 存在しているとし, 物質はそのき裂を通じて移動すると仮定する。 また，貯留層は不透水性の上下の岩相にはさまれ，巨視的には一 次元の物質移動を想定している。（2）式において左辺第 1 項は蓄 積項, 左辺第 2 項は微小領域への分散, 右辺第 1 項および第 2 項 はそれぞれ自然流の方向への分散および移流を表す項である。本 論文では非整数階微分を含む移流分散方程式 (fractional Advection Dispersion Equation) を以下 fADE と表記し， $\alpha, \gamma, b$ および $P e$ を $\mathrm{fADE}$ パラメータと定義する。 $b=0, \gamma=1, \alpha=1$ のときは従来 の移流分散方程式 (Advection Dispersion Equation, ADE) に帰着す る。fADE をフィールドに適用した事例においては, fADEによ り推定された地下流速と実測值が概ね一致する等の報告がなされ ており, fADEの有用性が指摘されている ${ }^{8)}$ 。

fADE は複雑系における数理モデルとして位置づけられ, 流動 媒体の浸透率分布と fADE との関係について報告 ${ }^{8)}$ があるなど, $\mathrm{fADE}$ パラメータと複雑性を有する流動媒体の特性との相関につ いては今後の重要な研究課題になるものと考えられる。地熱開発 の観点では, 地下構造調査の際には熱水の通路となるき裂構造の 把握が重要な課題の一つである。多くの場合, 地下き裂群には フラクタル性が存在することが報告されており, フラクタル性 を利用することで地下構造の特性を簡便に表現することができ る $^{9,10)}$ 。しかし, 地下の不可視性のために, フラクタル次元を 直接的に評価することは困難を伴う作業である。そこで本研究で はフラクタル性を有する断裂岩体中のき裂分布に着目し, fADE モデルと地下き裂のフラクタル性との関係について検討を行っ た。き裂のフラクタル性を考慮したネットワークモデルに基づく FRACSIM-3D ${ }^{11)}$ によって流動解析を行い, 地下構造が物質移動 に及ぼす影響について検証した。

\section{2. 計 算 方 法}

実フィールドの地下構造とトレーサー応答との関係を系統的に 観察することは容易ではない。本研究では, 地下構造変化に伴う

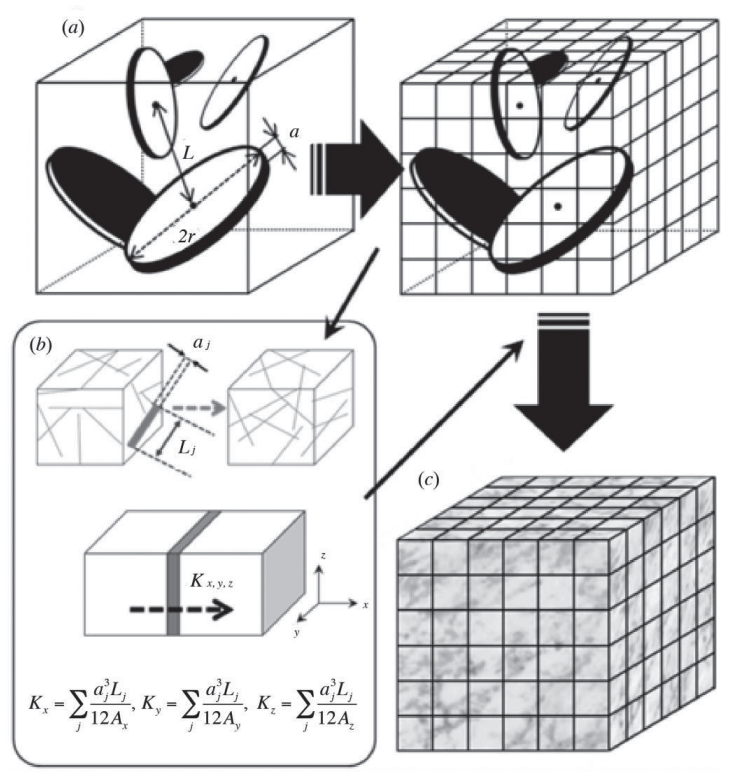

Fig.2 Converting a fracture network model to an equivalent continuum: (a) fractal fracture network; (b) calculation of "block to block" permeability; (c) equivalent continuum model with spatial distribution of permeability.

$\mathrm{fADE}$ パラメータの変化についての知見を得るために，き裂ネッ トワークモデル内の流動計算を行う FRACSIM-3D ${ }^{10,11,12)}$ を用い て, トレーサー解析を行った。はじめに, 地下き裂群を模擬した き裂ネットワークモデルを作成し, その後, き裂ネットワークに おける流動からトレーサー挙動を求めることで, き裂構造とト レーサー応答との関係性を調査した。

$2 \cdot 1$ フラクタル性を考慮したき裂ネットワークモデル

地下き裂群にはフラクタル性が存在し, 地下のき裂寸法と空 間分布はフラクタル則に従うことが報告されている ${ }^{13,14,15) 。}$ Watanabe らはき裂長さのフラクタル性を考慮したき裂ネット ワークモデルを提唱している ${ }^{11)}$ 。き裂ネットワークモデルの概 念図をFig. 2 に示す。このモデルでは円盤型き裂を仮定し, き裂 の半径にフラクタル性を考慮している。半径が $r$ 以上のき裂の総 数を $N$ とすると, 式 (3) が成り立つ。

$$
N=C_{f} r^{-D_{R}}
$$

ここで， $D_{R}$ はき裂長さのフラクタル次元， $C_{f}$ はき裂密度を表す パラメータである。Vermilye らはき裂長さとき裂幅が比例関係に あることを報告している ${ }^{6)}$ 。そこで, き裂幅 $a$ とき裂半径 $r$ との 間に (4) 式が成り立つと仮定する。

$a=\eta r$

ここで, 比例定数として文献 ${ }^{12)}$ を参考にして $\eta=1.0 \times 10^{-4}$ を用 いる。

次に, き裂分布の空間的な偏りを表現するため, レヴィフライ トモデル ${ }^{17,18)}$ をき裂ネットワークモデルに導入した。レヴィフ ライトモデルはき裂の移動距離にフラクタル性を有するランダム ウォークモデルのことであり, き裂の中心間隔 $L$ にいて (5) 式 が成り立つ。

$$
N_{L}=C_{L} L^{-D_{L}}
$$

$D_{L}$ はき裂分布に関するフラクタル次元， $C_{L}$ はき裂密度を表す定 数である。 
Table 1 Calculation conditions for tracer analyses by FRACSIM-3D.

\begin{tabular}{cccc}
\hline Parameters & & Value \\
\hline Pressure difference between inlet and outlet & $\Delta P$ & {$[\mathrm{MPa}]$} & 0.1 \\
Volume of fracture network model & {$\left[\mathrm{m}^{3}\right]$} & $100 \times 100 \times 100$ \\
Number of elements & & {$[\mathrm{Pa} \cdot \mathrm{s}]$} & $3 \times 10^{-4}$ \\
Viscosity of water & & & 10000 \\
Numbers of tracer particles & & {$[-]$} & 0.01 \\
\hline Injection time & $T_{i n}$ & &
\end{tabular}

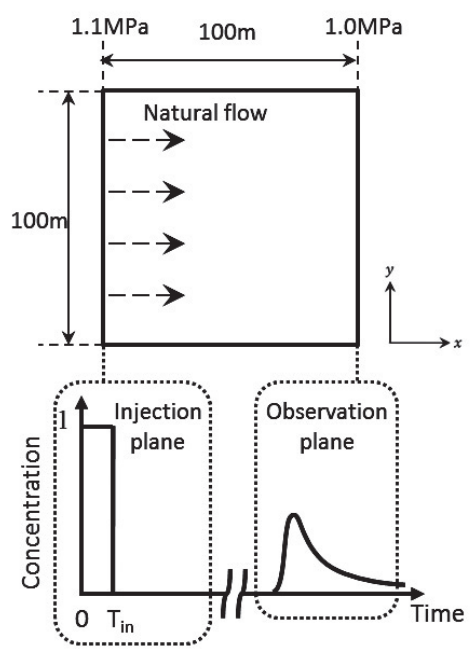

Fig.3 Schematic diagram of calculation condition for a tracer analysis.

本研究では, 以下の三種類のき裂ネットワークモデルを作成す ることにより，き裂長さおよびき裂分布に関するフラクタル性を 評価した。

（i）き裂半径を一定とし，き裂配置がランダムであるとしたモデ ル (Model U と表記する)

（ii）き裂長さのフラクタル性のみを考慮し，き裂配置をランダム としたモデル (Model D $D_{R}$ 表記する)

(iii)き裂長さのフラクタル性およびき裂分布のフラクタル性の両 方を考慮したモデル (Model $D_{L}$ と表記する)

\section{$2 \cdot 2$ 流動およびトレーサー応答の解析}

FRACSIM-3D ${ }^{11,12)}$ では，き裂分布を反映し，等価浸透率モデル を作成する。すなわち, き裂を発生させた計算領域を要素に分割 し, 要素境界の浸透率を計算する。計算に用いた境界条件と計算 条件を Table 1 に，境界条件の概念図をFig. 3 に示す。

ある要素境界における $x, y, z$ 方向の浸透率 $K_{x}, K_{x}, K_{x}$ は, それぞれ以下のように計算される。

$$
K_{x}=\sum_{j} \frac{a_{j}^{3} L_{j}}{12 A_{x}}, \quad K_{y}=\sum_{j} \frac{a_{j}^{3} L_{j}}{12 A_{y}}, \quad K_{z}=\sum_{j} \frac{a_{j}^{3} L_{j}}{12 A_{z}} ;
$$

$A_{x}, A_{y}, A_{z}$ はそれぞれ $x, y, z$ 座標と直交する要素境界の面積であ る。 $j$ は要素境界を交差するき裂に付した番号であり,$l_{j}$ ならび に $a_{j}$ はそれぞれ各き裂の要素境界を交差するき裂長さ, ならびに き裂幅である。(6) 式で求めた要素境界の浸透率に対してダルシー 則を適用し, 要素境界における各座標方向の流量 $Q_{x}, Q_{y}, Q_{z}$ を(7) 式により計算する。

$$
Q_{x}=A_{x} \frac{K_{x}}{\mu} \frac{\partial P}{\partial x}, \quad Q_{y}=A_{y} \frac{K_{y}}{\mu} \frac{\partial P}{y}, \quad Q_{z}=A_{z} \frac{K_{z}}{\mu} \frac{\partial P}{\partial z}
$$

ここで, $P$ は圧力, $\mu$ は流体の粘性係数を表す。解析対象は非圧 縮性流体であり, 貯留層内温度・圧力の範囲において水の粘性係 数はほぼ一定と仮定し，(8) 式の連続の式を用いて流動を計算する。

$$
\frac{\partial Q_{x}}{\partial x}+\frac{\partial Q_{y}}{\partial y}+\frac{\partial Q_{z}}{\partial z}=0
$$

流れ方向の上流面ならびに下流面にそれぞれ一定の圧力を与え， 側方境界面への流出入はないものとした (Fig. 3)。

次いで, 一つ一つのトレーサー粒子の移動時間および経路を計 算し, 全体のトレーサー挙動を求めていく。一つのトレーサー粒 子は, 粒子が存在する要素から隣接する要素へと移動を繰り返す ことによって, その移動経路が求められる。移動する方向は, 粒 子が存在する要素における各要素境界の流量の大きさに基づく確 率を計算することにより決定した。ただし, 粒子が存在する要素 に対して要素境界の流量が負になる場合, その方向に移動する確 率は零とする。流量から要素間の移動時間を算出し, 注入点から 観測点までの移動時間を積算することで，一つのトレーサー粒子 の滞留時間を求める。1 $10^{4}$ 個のトレーサー粒子を上流面からパル ス状に投入し, 下流面に到達したトレーサー粒子の個数を濃度と し，一定期間に到達するトレーサーの頻度分布を基にトレーサー 応答を評価した。

実フィールドにおけるトレーサー試験では, 注入井ならびに観 測井間をトレーサーが移動するため, その移動は 2 次元あるいは 3 次元現象として解析することが要求される。一方で, (2) 式は一 次元物質移動を表現したものではあるものの, 天然き裂のフラク タル特性等の貯留層構造と, (2) 式中の非整数階微分の階数との 関係を明らかにすることができれば，より高次元における非整数 階微分を用いた物質移動モデルの開発にも有効であることが考え られる。以上の観点から, 本研究では, 一次元物質移動における トレーサー応答を評価し, 非整数階微分の階数との関係について 検討した。

\section{$2 \cdot 3$ き裂ネットワークモデルの評価}

Model $U$ では, き裂半径 $r$ を $1.0 \mathrm{~m}$ に固定した。Model $D_{R}$ なら びに Model $D_{L}$ では, き裂半径 $r$ を $0.5-25 \mathrm{~m}$ で与えた。すなわち, 計算要素より小さな寸法のき裂による要素境界における浸透率へ の影響を無視できるものとし, 最小のき裂長さは計算要素の一辺 と同じ長さ $(1 \mathrm{~m})$ とした. また最大のき裂長さは計算領域の半分 $(50 \mathrm{~m})$ とし, 単一き裂が注入地点と観測地点間を貫通する場合を 除外している。き裂長さのフラクタル次元 $D_{R}$ は, 平面の円盤形 き裂を三次元上に分布させたため, $2.0-3.0$ の範囲内で与えた。 き裂密度は, 異なる $D_{R}$ を用いた場合も一定の值になるように, 
き裂密度を表すパラメータ $C_{f}$ ( (3) 式) の值を変化させることに よって調整した。このとき, き裂密度は, $\mathrm{x}$ 軸方向に引いたライ ン上を交差するき裂の数から算出し, 9 本のラインの算術平均を そのき裂ネットワークモデルのき裂密度 $\left[\mathrm{m}^{-1}\right]$ とした。また, 単 位体積に対するき裂面積 $\left[\mathrm{m}^{2} / \mathrm{m}^{3}\right]$ を評価してき裂密度を算出した 場合も同等の值となることを確認している。このき裂密度に従っ て, (3) 式よりき裂の総数 $N$ が算出される。Model $D_{L}$ を用いる場 合は，はじめに (3) 式によりき裂密度およびき裂の総数 $N$ を決定 することで, (5) 式の $N_{L}$ に代入する。き裂分布に関するフラクタ ル次元 $D_{L}$ は, $D_{R}$ 同様 $2.0-3.0$ の範囲内で与えた。同じ計算条 件について, き裂の配置のみを乱数によって変化させたき裂ネッ トワークモデルを 100 個作成し, それぞれを用いた流動計算を 行った。本研究では, 100 個のき裂ネットワークモデルから得ら れた結果の平均值を評価した。

\section{$2 \cdot 4$ fADE パラメータの推定}

トレーサー応答のフィッティングには, 最適化アルゴリズム ADS (Automated Design Synthesis) ${ }^{20)}$ を用いることにより，それ ぞれのトレーサー応答に対する最適な $\mathrm{fADE}$ パラメータ $(\alpha, \gamma, b$, $\mathrm{Pe}$ ) を決定した。ADS は, 制約付き非線形多変数関数の最小值を 求めることができる汎用的なプログラムである。最適化問題の目 的関数を fADE モデルの数值解とトレーサー応答との平均二乗誤 差 (Root Mean Square Error, RMSE) とした。(2) 式の fADE モデル の数值解は, 差分法によって求めることができる ${ }^{19)}$ 。平均二乗 誤差は (9) 式で与えられる。

$$
R M S E=\sqrt{\sum_{i=1}^{n}\left(C_{f A D E}^{i}-C_{o b j}^{i} / n\right)}
$$

ここで, $C_{f A D E}$ は(2) 式の fADEモデルの数值解, $C_{o b j}$ は FRACSIM-3D で計算されたトレーサー濃度, $n$ はデータ点の総数 を表す。本研究ではデータ点の総数 200 点にて評価をおこなった。

\section{3. 計算結果と考察}

\section{$3 \cdot 1$ き裂ネットワークモデルと浸透率分布}

はじめに, Model $D_{R}$ を用いてき裂ネットワークモデルを作成 した。 $D_{R}$ がき裂ネットワークの分布に及ぼす影響を Fig. 4 に示 す。このとき, き裂密度は一定 $\left(1.5 \mathrm{~m}^{-1}\right)$ とした。 $D_{R}$ の増加に伴 い, 半径の大きいき裂が減少し, 小さいき裂が増加しており, 分 布するき裂半径が均一化することで, より均質体に近づいている ことがわかる。Fig. 5 には, き裂ネットワークモデルにおける要 素の浸透率 $k\left[\mathrm{~m}^{2}\right]$ のヒストグラムを示している。ここで, 要素 の浸透率とは, 1 つの要素に対して6つの要素境界の浸透率 ( (6) 式) の算術平均をその要素の浸透率 $k(x, y, z)$ としている。 $D_{R}=2.0$ においては, $k=10^{-10}\left[\mathrm{~m}^{2}\right]$ の浸透率を示寸要素の割合が最も高く, $D_{R}=2.5$ および $D_{R}=3.0$ においては, $k=10^{-13}\left[\mathrm{~m}^{2}\right]$ の浸透率を示 寸要素の割合が最も高かった。このことから， $D_{R}$ の増加に伴い 低浸透率の要素の割合が増加すると言える。これは $D_{R}$ の増加に 伴い微小き裂, 寸なわち浸透性の低いき裂が増加したことに起因 すると考えられる。

き裂長さのフラクタル性の影響を評価する目的で, Model U, すなわち, き裂半径 $r$ を固定し $(r=1.0 \mathrm{~m})$, き裂配置をランダム にしたき裂ネットワークモデルを作成した。Model Uのき裂ネッ トワークの一例をFig. 6 に, 浸透率分布をFig. 7 に示す。Fig. 7 は, 100 個のき裂ネットワークモデルの平均值である。Model U では, 要素の浸透率の $95 \%$ 以上が $k=10^{-13}\left[\mathrm{~m}^{2}\right]$ もしくは $k=10^{-14}\left[\mathrm{~m}^{2}\right]$ を示しており, き裂長さのフラクタル性を考慮したモデル Model $D_{R}$ と比較すると, 均質体に近い浸透率分布であるといえる。

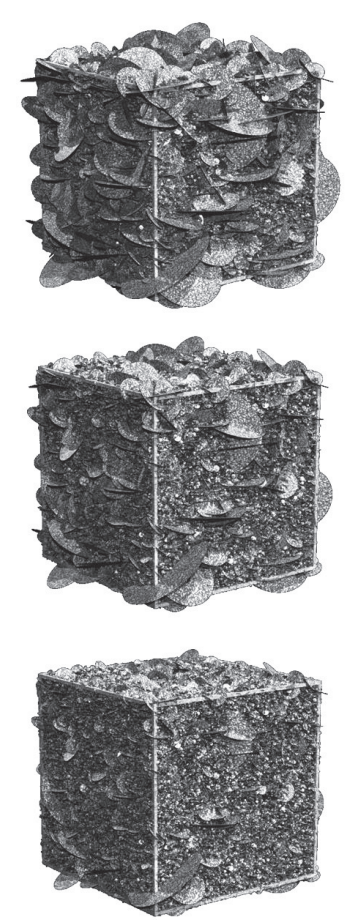

Fig.4 Illustration of fracture networks of Model $D_{R}$ : (a) $D_{R}=2.0$ (b) $D_{R}=2.5$ (c) $D_{R}=3.0$. Fracture density is $1.5 \mathrm{~m}^{-1}$.

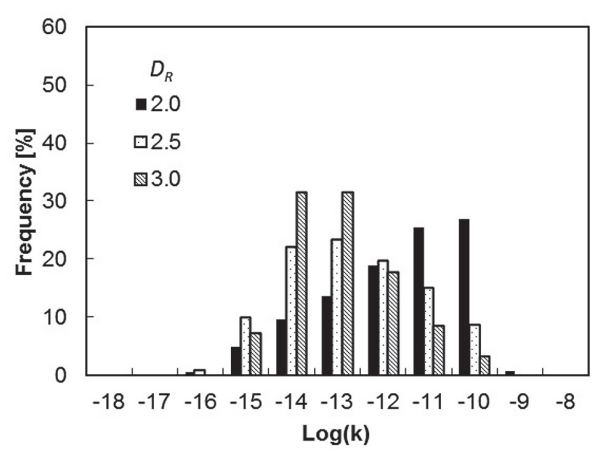

Fig.5 Permeability distribution in fracture networks with different $D_{R}$ values. Fracture density is $1.5 \mathrm{~m}^{-1}$.

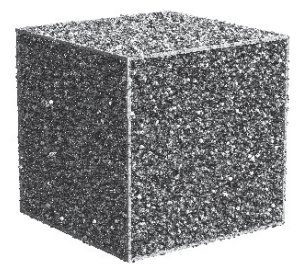

Fig.6 Illustration of fracture network of Model $U$ with $r=1.0 \mathrm{~m}$. Fracture density is $1.5 \mathrm{~m}^{-1}$.

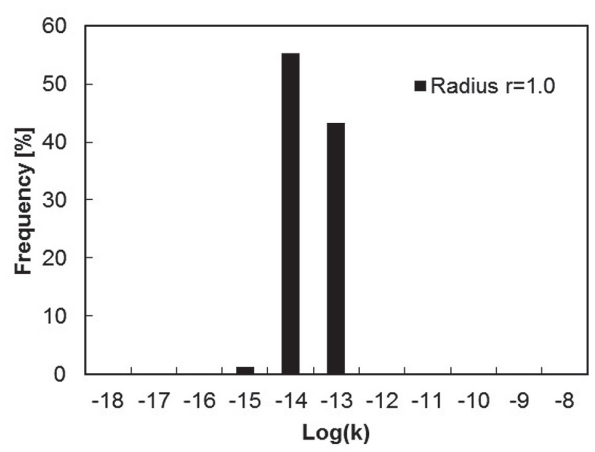

Fig.7 Permeability distribution in fracture network (Model $U$ ) with $r=1.0 \mathrm{~m}$. Fracture density is $1.5 \mathrm{~m}^{-1}$. 

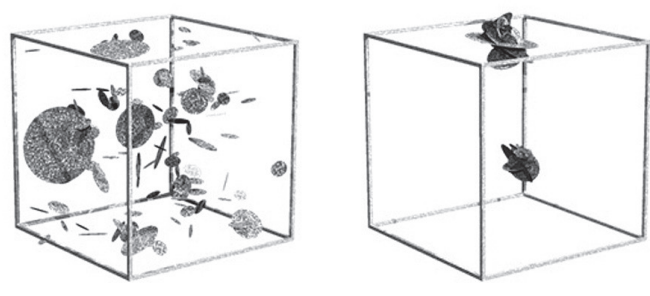

Fig.8 Illustration of fracture networks of (a) Model $D_{R}$ (b) Model $D_{L}$. The number of fractures is 100 .

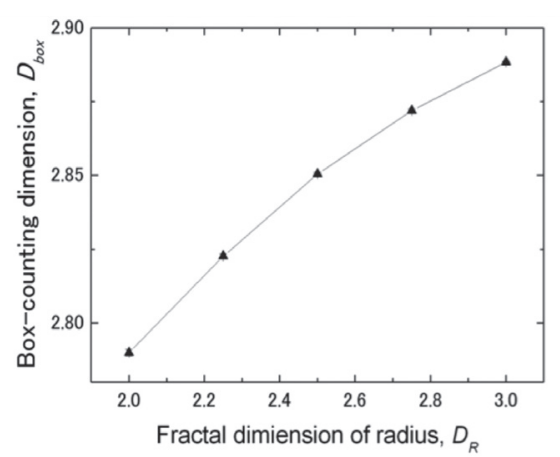

Fig.10 Box-counting dimension $D_{b o x}$ and fractal dimension of radius $D_{R}$. Fracture density is $0.7 \mathrm{~m}^{-1}$.

つづいて, Model $D_{L}$ の特性について観察した。Model $D_{R}$ と Model $D_{L}$ のき裂ネットワークモデルの比較を Fig. 8 に示す。こ こでは両モデルの違いを明確にするために，少数のき裂を分布さ せた $\left(N=N_{L}=100\right)$ 。このとき, $D_{R}=2.5$ および $D_{L}=2.5$ とした。 Model $D_{R}$ の場合, き裂は空間全体に分散していることが確認で きる。一方, Model $D_{L}$ では, き裂分布のフラクタル性を考慮す ることにより，き裂位置が局在化していることが確認される。

Model $D_{L}$ における浸透率分布を Fig. 9 に示す。このとき, $D_{R}$ $=2.5$, き裂密度は一定 $\left(1.5 \mathrm{~m}^{-1}\right)$ とした。Fig. 9 より, 浸透率分布 の $D_{L}$ 依存性は極めて小さいことがわかる。しかしながら, Fig. 5 に示される Model $D_{R}$ の結果 $\left(D_{R}=2.5\right)$ と比較すると, 高浸透率を 示す要素の割合が増加していることが確認される。これは, き裂が 局所化することにより高浸透領域が形成されたためと考えられる。

\section{$3 \cdot 2$ ボックスカウンティング法の適用結果}

フィールドで得られたき裂分布に基づきフラクタル次元を算出 する場合, ボックスカウンティング法が適用されている ${ }^{13)}$ 。3 次元領域におけるボックスカウンティング法では, 領域を立方体 に分割し, 分析対象を一部でも含むボックスの個数を数える手法 である。分割する立方体の一辺の長さを $2^{\mathrm{n}}(\mathrm{n}=0, \pm 1, \pm 2, \cdots)$ 倍 に変化させていき, 分割した立方体の一辺の長さとボックスの個 数を両対数プロットした傾きからフラクタル次元を求めることが できる。 $D_{b o x}$ が 3 に近づくほど 3 次元的にき裂が分布, すなわ ち, き裂が均一に配置されていると言える。本研究では, Model $D_{R}$ および Model $D_{L}$ についてのボックスカウンティング次元 $D_{b o x}$ を評価し， $D_{b o x}$ と $D_{R}$ ならびに $D_{L}$ との関連性を調べた。はじめ に, Model $D_{R}$ により得られた $D_{b o x}$ と $D_{R}$ との関係を Fig. 10 に示 す。このときのき裂密度は $0.7 \mathrm{~m}^{-1}$ である。 $D_{R}$ と $D_{b o x}$ の間には 正の相関があることがわかる。上述したように, D box が 3 に近 づくほどき裂が均一に分布していると考えられるため, $D_{R}$ の増

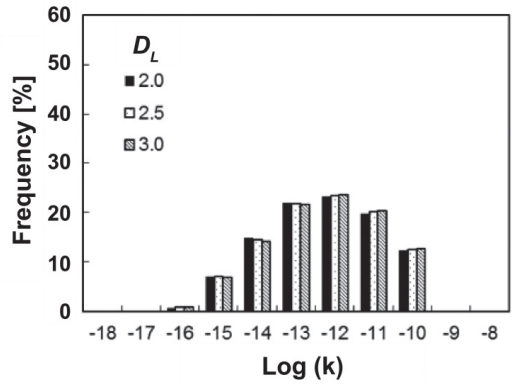

Fig.9 Permeability distribution in fracture networks with different $D_{L}$ values. $D_{R}=2.5$, and fracture density is $1.5 \mathrm{~m}^{-1}$.

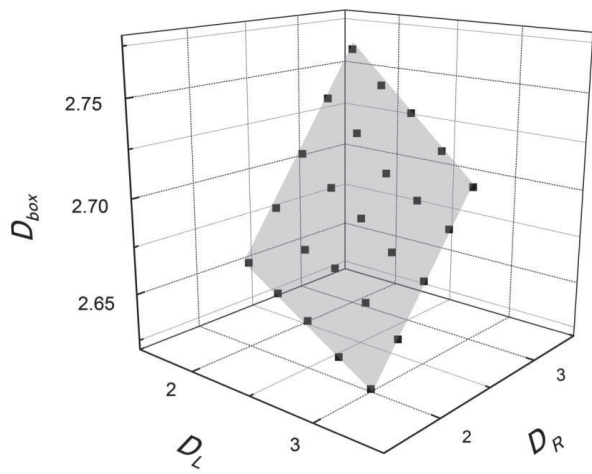

Fig.11 Relationship between three fractal dimensions; $D_{b o x}$, $D_{R}$, and $D_{L}$. Fracture density is $0.7 \mathrm{~m}^{-1}$.

加に伴いき裂が均一に分散する傾向のあることが定量的に確認で きる。つづいて, Model $D_{L}$ にボックスカウンティング法を適用 し, 得られた $D_{b o x}$ および $D_{R}, D_{L}$ の関係を Fig. 11 に示す。この ときのき裂密度は $0.7 \mathrm{~m}^{-1}$ である。 $D_{L}$ の減少に伴い, $D_{b o x}$ が増加 していることから， $D_{L}$ の減少に伴いき裂が均一に分散すること がわかる。き裂密度が一定である場合, $D_{b o x}, D_{R}, D_{L}$ の関係は 一つの平面で表現でき, き裂密度 $0.7\left[\mathrm{~m}^{-1}\right]$ の場合, (10) 式を満た すことがわかった。

$$
D_{\text {box }}=0.09 D_{R}-0.052 D_{L}+2.59
$$

き裂密度が増加すると, 3 種類のフラクタル次元を関係づける平 面は $D_{b o x}$ に対する切片の值を増加させながら移動する。この時, 平面は $D_{R} D_{L}$ 平面に対して平行に近づくように傾きを変化させな がら移動することを確認した。き裂密度が $1.0 \mathrm{~m}^{-1}$ 以上の場合は, $D_{R}, D_{L}$ によらず $D_{b o x}$ がほぼ 3 に近い值を示すことを観察してお り, き裂の数を増やすことによって, $D_{b o x}$ の最大值である 3.0 に 飽和寸るように傾きが変化すると考えられる。

き裂密度が低い場合は，(10) 式のように $D_{b o x}, D_{R}, D_{L}$ を線形 的に関係づけられることがわかった。ここで示した結果は, き裂 密度を一定にして得られた結果であるため, 今後, フラクタル次 元のき裂密度依存性を定量評価することが求められる。一方, き 裂密度が高い場合, Model $D_{R}$ あるいは Model $D_{L}$ のどちらのモデ ルも $D_{b o x}$ が 3.0 に近づき，大きな值を示した。このことから，き 裂密度が高い場合, き裂は偏在せずに分布することがわかった。 特にき裂密度が高い場合の Model $D_{L}$ では, $D_{L}=2.0-3.0$ の範囲 でき裂の中心間隔にフラクタル性を有しているにも関わらず，き 裂分布に大きな差が見られなかった。すなわち, き裂密度が高い 場合の $D_{L}$ 依存性は極めて小さいことがわかった。これは, き裂 の枚数が多くなることで, き裂の中心間隔が平均化されたためだ 


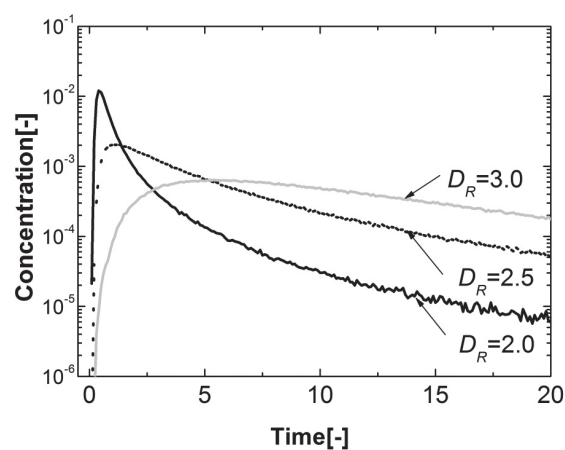

Fig.12 Tracer curves computed by FRACSIM-3D for fracture networks with different $D_{R}$ values. Fracture density is $1.5 \mathrm{~m}^{-1}$.

と考えられる。

\section{$3 \cdot 3$ トレーサ一応答結果}

$D_{R}$ ならびに $D_{L}$ が同一条件の下で, 配置位置のみ異なる 100 個のき裂ネットワークモデルを用意し，それぞれのき裂ネット ワークモデル内でのトレーサー応答を計算した。以下に示すト レーサー応答結果は, 100 個のトレーサー応答の平均值である。

$D_{R}$ を変化させた時のトレーサー応答の変化挙動を Fig. 12 に示 す。このときのき裂密度は $1.5 \mathrm{~m}^{-1}$ とした。トレーサー応答の濃 度ならびに距離, 時間をそれぞれ, トレーサーの注入濃度, 坑井 間距離, トレーサーの平均滞留時間によって無次元化した。 $D_{R}=$ 2.0 では早い時間に鋭いピークをもつトレーサー応答が観察され ている。 $D_{R}$ が 2.0 から 3.0 に増加寸るのに伴い, トレーサー応答 が遅延するとともに幅の広いピークを呈する傾向がある。この結 果は, $D_{R}$ の増加に伴ってき裂半径の小さいき裂群が増加し, 低 い浸透率を有する領域が相対的に広がるためと考えられる。

つづいて, Model Uに基づくトレーサー応答結果を Fig. 13 に 示す。このときのき裂密度は $1.5 \mathrm{~m}^{-1}$ とした。比較のため, 同一 のき裂密度の Model $D_{R}$ の結果を合わせて示す。このときの $D_{R}$ は 2.5 とした。き裂半径が一定の Model Uでは, トレーサー応答 の全体的な挙動はほぼ ADE モデルで表現できていることが観察 される。一方, Model D $D_{R}$ 基づいたトレーサー応答は, Model U におけるトレーサー応答よりも ADE で表現できないテールのあ るトレーサーカーブ, すなわち non-Fickian 挙動がより顕著であ ることが観察される。このことから，き裂長さのフラクタル性 が non-Fickian 挙動を誘起している原因の 1 つであると推察され る。き裂長さにフラクタル性がある Model $D_{R}$ には, 様々な半径 および幅を有するき裂が存在する。そのため, き裂半径が一定 の Model U と比較すると, 浸透率の分散が大きい。したがって, Model Uに比べると Model $D_{R}$ では, 注入位置から観測位置まで のトレーサー粒子の移動時間に, よりばらつきが発生すると考え られる。このため, Model $D_{R}$ では遅延挙動が顕著となり, nonFickian 挙動が現れたと推察される。

Model $D_{L}$ に基づくトレーサー応答結果を Fig. 14 に示す。この ときの $D_{R}$ は 2.5 とした。 Model $D_{L}$ に基づくトレーサー応答は, Model $D_{R}$ に基づくトレーサー応答よりもピーク值が早い時間に 現れることが観察できる。き裂空間分布のフラクタル性を考慮し た場合, 要素の浸透率におけるばらつきはき裂長さのフラクタル 性を考慮した場合よりも大きいと考えられることから，流速の分 散が大きくなり，トレーサー応答に大きく影響を及ぼしたものと 考えられる。しかしながら, $D_{L}$ が 2.0-3.0の範囲においては, 卜 レーサー応答に及ぼす $D_{L}$ の影響は小さく, かつ, その結果はラ ンダムな空間分布の場合に比較的近い傾向を示している.このこ

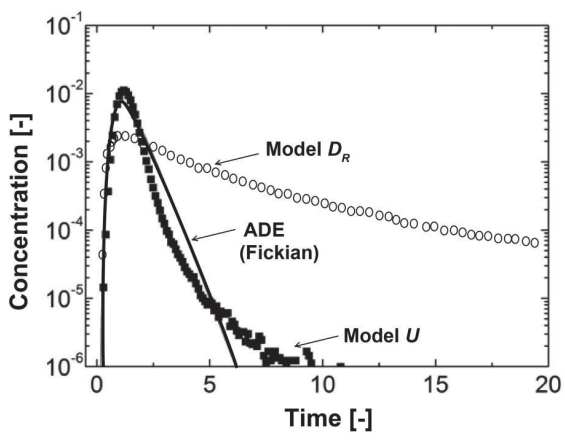

Fig.13 Tracer curves computed by FRACSIM-3D for Model $U$ and for Model $D_{R}$ and fitted curve based on the ADE. $D_{R}=2.5$ for Model $D_{R}$, and fracture density in each model is $1.5 \mathrm{~m}^{-1}$.

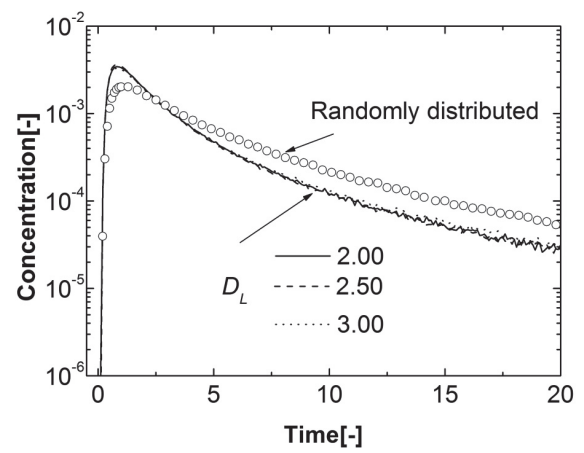

Fig.14 Tracer curves computed by FRACSIM-3D for fracture networks with different $D_{L}$ values. $D_{R}=2.5$, and fracture density is $1.5 \mathrm{~m}^{-1}$.

とから, き裂空間分布のフラクタル性がトレーサー応答に及ぼす 影響は, き裂長さのフラクタル性が及ぼす影響と比較して, 顕著 ではないことが推察される。

\section{$3 \cdot 4$ フィッティング結果}

fADE モデルに関する理論的研究では, フラクタル次元と fADE 構成パラメータとの間には関係性があることが示されてい る $^{6,7)}$ 。しかしながら，実際のき裂構造のパラメータとの定量的 な関係については明らかになっていない。もし，トレーサー応答 を基に評価した fADE 構成パラメータから, 相関関係を用いて地 下き裂ネットワークにおけるき裂長さのフラクタル次元を推定で きるようになると, き裂構造の推定ならびに貯留層設計において 利点が大きいものと考えられる。

$3 \cdot 3$ 節では, き裂密度が高い場合, $D_{L}$ の影響はトレーサー 応答に顕著に現れないことを示した。したがって,ここでは, Model $D_{R}$ を用いて, トレーサー応答を算出し, $D_{R}$ と $\mathrm{fADE}$ パラ メータとの関係を評価した。

得られたトレーサー応答の一例に対して, fADE モデルと ADE モデルを適用した結果を Fig. 15 に示す。このとき, き裂密度は 1.5 $\mathrm{m}^{-1}, D_{R}=2.5$ とした。なお, $\mathrm{ADE}$ モデルは (2) 式において $b=0$, $\gamma=1, \alpha=1$ としたものである。fADE モデルは ADE モデルと比 較して無次元時間が 10 以降に現れるテール部分をよりよく表現 していることがわかる。

Fig. 16 (a) には, き裂密度が $1.5 \mathrm{~m}^{-1}$ のときの fADE 構成パラ メータ $(\alpha, \gamma, b, P e)$ と $D_{R}$ との関係を示す。值は, 100 個のき 裂ネットワークモデルの平均值, エラーバーは標準偏差を表して いる。Fig. 16 (a) より, $D_{R}$ の増加に伴い $\alpha$ は増加し, $P e$ は減少 した。 $D_{R}$ が小さい場合, 半径の大きいき裂が分布し, 卓越した 流路を形成しやすいのに対し, $D_{R}$ が大きい場合, 半径の小さい 


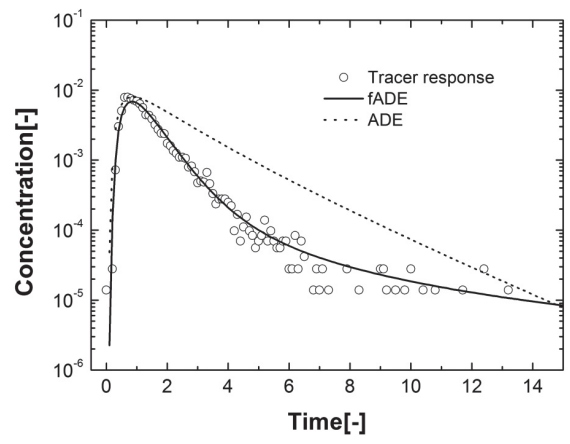

Fig.15 Tracer curves computed by FRACSIM-3D for Model $D_{R}$ and fitted curves based on ADE and the fADE models. $D_{R}=2.5$, and fracture density is $1.5 \mathrm{~m}^{-1}$.

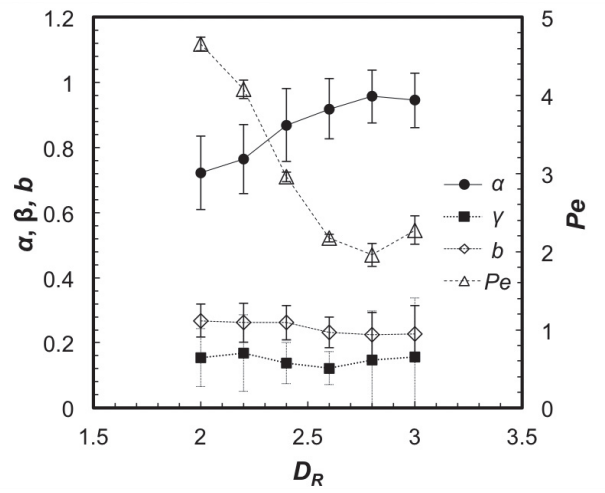

(a)

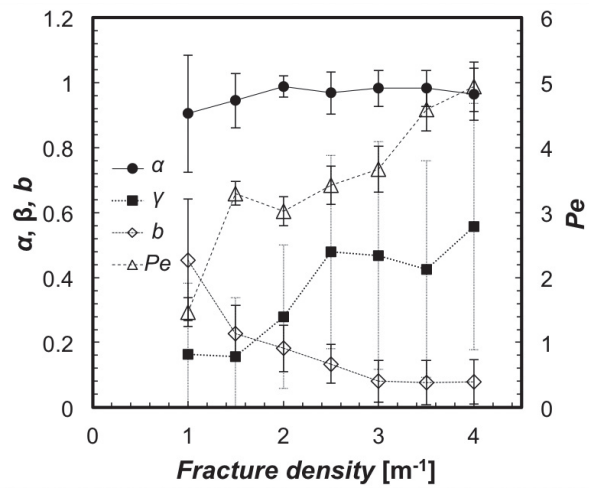

(b)

Fig.16 The fitting result of tracer analyses based on the fADE : Relationship between the fADE parameters $(\alpha, \gamma, b, P e)$ and (a) fractal dimension of fracture radius $\left(D_{R}\right)$ at fracture density of $1.5 \mathrm{~m}^{-1}$, and (b) fracture density at $D_{R}=3.0$.

き裂が多数分布し，分散が起きやすいと考えられる。ここで， $\alpha$ $=1$ の場合, (2) 式の右辺第 1 項は ADE モデルにおける分散項と 同等であり, $\alpha \rightarrow 0$ の場合, その項は移流項に近似される。また, ペクレ数Pe は移流と分散の割合を表しており, Pe が大きい方が 移流が支配的であり，小さい方が分散が支配的であることを表し ている。このことから， $D_{R}$ に対する $\alpha$ ならびに $P e$ の変化は，パ ラメータの理論的解釈と定性的に一致している。また， $\gamma$ および $b$ は $D_{R}$ の変化に依らずほぼ一定值を示し， $D_{R}$ に依存性が無いこ とを示している。

Fig. 16 (b) には, $D_{R}$ が 3.0 のときの fADE 構成パラメータとき 裂密度の関係を示す。 $\alpha$ はき裂密度に依らずほぼ一定值を示して おり, き裂密度に依存しないことがわかる。Pe はき裂密度の増 加に伴い増加している。これは, き裂密度が増加することによっ て, き裂間の連結性が高まり, 移流が支配的になったことに起因 していると考えられる。また, き裂密度が小さい方が $\gamma$ の值は小 さく, $b$ の值は大きいことが観察される。 $\gamma$ ならびに $b$ を含む (2) 式中の左辺第二項は, 二次的なき裂への拡散を表しており, き裂 密度が小さい場合に, 二次的なき裂への拡散が現れたと推察され る。これらの $\gamma$ ならびに $b$ 傾向は, パラメータの理論的な解釈 と整合性がある。

き裂密度が 1.0-4.0 $\mathrm{m}^{-1}, D_{R}$ が 2.0 - 3.0 の場合の fADE 構成パ ラメータの関係に基づき, 重回帰分析を行った。目的変数を $D_{R}$ とし, 説明変数を fADE 構成パラメータ $\alpha, \gamma, b, P e$ とした。重 回帰分析により得られた推定式を以下に示す。

$$
D_{R}=2.60 \alpha+0.628 \gamma-0.192 b-0.037 P e+0.257
$$

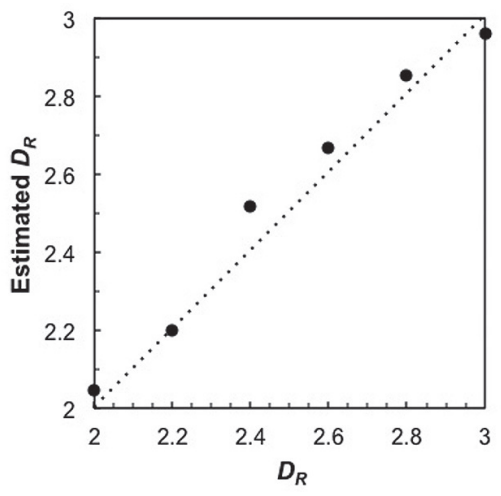

Fig.17 The precision of the predictive model. Fracture density is $1.5 \mathrm{~m}^{-1}$.

（11）式を用いて $D_{R}$ を推定した場合の推定精度を Fig. 17 に示 す。横軸はき裂ネットワークモデルの $D_{R}$, 縦軸はトレーサー応答 より得られたフィッティングパラメータを上述の式 (11) に代入 して求めた $D_{R}$ である。得られた $D_{R}$ は正の相関を示しているこ とがわかる。このときの決定係数は $R^{2}=0.937$ であり, 比較的高 い精度で $D_{R}$ を推定できることが認められた。

既存のき裂ネットワークに基づく貯留層モデルでは, き裂の特 徵を決定付ける入力パラメータは解析者の主観に依ることが多 く, また多大な計算コスト, 計算時間を要するものであった。本 研究で得られた結果は, 実フィールドから得られるトレーサー応 答を fADE によって解析することにより, 簡便に $D_{R}$ が推定がで きる可能性を示している。一方， $3 \cdot 3$ 節で記載したように，卜 
レーサー応答はき裂空間分布のフラクタル次元 $D_{L}$ に大きく依存 しないため, (11) 式で与えられる相関関係は一般的であることが 予想され，本相関関係を用いて $D_{R}$ を簡便に評価できることが期 待される. 本論文で提案する手法は, き裂ネットワークモデルに おけるき裂長さ分布に関するフラクタル次元を実際のフィールド データに基づき決定できる手法を提供し，解析者の主観に依らな い客観的評価を可能とし, 貯留層モデル構築の効率化を図ること が期待できる。今後, フィールドデータなどに基づいて, 式の妥 当性を評価することが期待される。

\section{4. 結言}

き裂長さあるいはき裂分布のフラクタル性を考慮したき裂ネッ トワークモデルを作成し，き裂分布の特性ならびにトレーサー 応答への影響を評価した。き裂長さのフラクタル性を考慮した Model $D_{R}$ では, き裂長さのフラクタル次元 $D_{R}$ 増加に伴い, き裂 寸法が均一に近づくことが観察された。このとき， $D_{R}$ の増加に 伴い低浸透率を示寸要素の割合が増加した。き裂長さならびにき 裂分布のフラクタル性を考慮した Model $D_{L}$ では, き裂密度が低 いときはき裂位置が局在化することが確認されたが, き裂密度が 高い場合は, き裂分布のフラクタル次元 $D_{L}$ の浸透率分布ならび にボックスカウンティング次元への影響は極めて小さかった。き 裂半径を一定とし, き裂配置をランダムとした Model Uにおけ るトレーサー応答は, 均質媒体における流動現象 (Fickian 挙動) に近い傾向を示した。一方, き裂長さのフラクタル性を考慮した Model $D_{R}$ のトレーサー応答では non-Fickian 挙動が顕著であった ことから, き裂長さのフラクタル性が non-Fickian 挙動の原因の 1 つであると推察される。

また，き裂密度が高い場合の Model $D_{R}$ に対して fADE モデル を適用した。フィッティングにより得られた $\mathrm{fADE}$ パラメータは, $D_{R}$ およびき裂密度の変化に対して, 理論的な解釈と整合性のあ る傾向を示した。重回帰分析により fADE パラメータと地下フラ
クタル次元 $D_{R}$ との関係式

$$
D_{R}=2.60 \alpha+0.628 \gamma-0.192 b-0.037 P e+0.257
$$

を導いた。上述の式を用いることにより，き裂ネットワークモ デルにおけるき裂長さ分布に関するフラクタル次元をを実際の フィールドデータに基づき決定できるため, 解析者の主観に依ら ない客観的評価を可能とし, 貯留層モデル構築の効率化を図るこ とが期待できる。

\section{References}

1) L. W. Gelhar, A. L. Gutjahr and R. L. Naff: Water Resources Research, 15 (1979) , 13871397.

2) S. P. Neuman and Y.K. Zhang: Water Resources Research, 26 (1990), 887-902.

3) B. Berkowitz, H. Scher and S. E. Silliman: Water Resources Research, 36 (2000) , 149-158.

4) D. A. Benson, S. W. Wheatcraft and M. M. Meerschaert: Water Resources Research, 36 (2000), 1403-1412.

5) R. Schumer, D. A. Benson and M. M. Meerschaert: Water Resources Research, 39 (2003), 1296.

6) S. Fomin, V. Chugunov and T. Hashida: Proceedings of the Royal Society A: Mathematical, Physical and Engineering Sciences, 461 (2005), 2923-2939.

7) S. Fomin, V. Chugunov and T. Hashida: Transport in Porous Media, 81 (2009) , 187-205.

8) Y. Zhang, D. A. Benson and D. M. Reeves: Advances in Water Resources, 32 (2009), 561581.

9) M. Bagde: Engineering Geology, 63 (2002) , 141-155

10) K. Watanabe and H. Takahashi: Proc. 18th Workshop on Geothermal Engineering Stanford University (1993), pp. 119-124.

11) K. Watanabe and H. Takahashi: Journal of Geophysical Research 100 (1995), 521-528.

12) Z. Jing, J. Willis-Richards, K. Watanabe and T. Hashida: Journal of Geophysical Research 105 (2000), 23663-23679.

13) I. G. Main, S. Peacock and P. G. Meredith: Pure and Applied Geophysics, 133 (1990) , 283304.

14) E. Bonnet, O. Bour, N. E. Odling, P. Davy, I. Main, P. Cowie, B. Berkowitz: Reviews of Geophysics, 3 (2001) , 347-383.

15) T. Hirata: Pure and Applied Geophysics, 131 (1989), 157-170.

16) J. M. Vermilye and C. H. Scholz: Journal of Structural Geology, 17 (1995) , 423-434.

17) Benoit B. Mandelbrot: 1981 Yearbook of Science and the. Future, Encylcopaedia Britannica, Inc., Chicago, 1980, pp. 168-181.

18) C.C. Lee, C.H. Lee, H.F. Yeh, and H.I. Lin: Environmental Earth Sciences, 63 (2010), 1199-1211.

19) R. Chiba, S. Fomin, V. Chugunov, T. Takahashi and Y. Niibori: Proc. 4th International Workshop on Water Dynamics, 133 (2008) , 75-78.

20) G. N. Vanderplaats and H. Hashimoto: Computers and Structures, 24 (1986), 13-21. 